Guru Tua : Jurnal Pendidikan dan Pembelajaran

p-ISSN : 2623-2359

Vol. 2, No. 1, Mei 2019, Hal. 29-36

e-ISSN : 2623-2340

\title{
PEMBENTUKAN KARAKTER SISWA BERBASIS PENDIDIKAN SENI BUDAYA DI MAN 1 PALU
}

\author{
Syamsuddin \\ Program Studi Bahasa dan Sastra Indonesia, Fakultas Sastra,Universitas Alkhairaat \\ syam.50TV@gmail.com
}

\begin{abstract}
ABSTRAK
Penelitian ini berjudul 'Membentuk Karakter Siswa Berbasis Pendidikan Seni Budaya di MAN 1 Palu'. Permasalahan dalam penelitian ini adalah (1) Apa strategi pendidikan karakter berbasis seni budaya di MAN 1 Palu, (2) Apa saja faktor pendukung dan penghambat pendidikan karakter berbasis seni budaya di tingkat pendidikan SMA , (3) siswa, siswa, penyedia pendidikan lokal tentang implementasi dan manfaat pendidikan karakter berbasis seni dan budaya. Penelitian dilakukan di MAN 1 Palu dengan pertimbangan (1) MAN 1 Palu dilandasi sebagai salah satu sekolah yang aktif dalam pengembangan seni dan budaya, (2) Sebagai sekolah yang aktif ternyata memiliki banyak prestasi baik di tingkat lokal dan nasional. Hasil penelitian ini menunjukkan: (1) Pendidikan karakter berbasis seni dan budaya di MAN 1 Palu menggunakan metode pembiasaan (2) Sekolah memiliki basis pendidikan karakter yang ditonjolkan, (3) mata pelajaran seni budaya telah diterapkan dalam pendidikan karakter, (4) Karakter pendidikan tidak eksklusif dalam pelajaran seni budaya tetapi di seluruh mata pelajaran.
\end{abstract}

Kata kunci : Pendidikan, Karakter, Seni Budaya

\begin{abstract}
This research is titled 'Forming Student Character Based on Cultural Arts Education at MAN 1 Palu'. The problems in this study are (1) What is the strategy of cultural arts-based character education in MAN 1 Palu, (2) What are the supporting and inhibiting factors of cultural arts-based character education at the level of senior high school education, (3) students, students, local education providers about the implementation and benefits of art and culture-based character education. The study was conducted at MAN 1 Palu with consideration (1) MAN 1 Palu was predicated as one of the schools active in the development of art and culture, (2) As an active school it turned out that it had many achievements both at the local and national level. The results of this research to show: (1) Art and cultural based character education in MAN 1 Palu using habituation methods, (2) Schools have character education bases that are highlighted, (3) Cultural arts subjects have been implemented in character education, (4) Education characters are not exclusive in cultural arts lessons but throughout subjects.
\end{abstract}

Keywords: Education, Character, Cultural Arts

\section{PENDAHULUAN}

Pendidikan adalah suatu usaha sadar dan sistematis dalam mengembangkan potensi peserta didik. Pendidikan juga merupakan suatu usaha masyarakat dan bangsa dalam mempersiapkan generasi mudanya bagi keberlangsungan kehidupan yang lebih baik di masa depan. Keberlangsungan itu ditandai oleh pewarisan budaya dan karakter yang telah dimiliki sebuah bangsa. Dalam proses pendidikan budaya dan karakter bangsa, secara aktif peserta didik 
mengembangkan potensi dirinya, melakukan proses internalisasi dan penghayatan nilai-nilai menjadi kepribadian mereka dalam bergaul di masyarakat, mengembangkan kehidupan masyarakat yang lebih sejahtera, serta mengembangkan kehidupan bangsa yang bermartabat. Dalam Kamus Bahasa Indonesia kata "karakter" diartikan dengan tabiat, sifat-sifat kejiwaan, akhlak atau budi pekerti yang membedakan seseorang dengan yang lain (watak). Dengan kata lain, karakter mengacu kepada serangkaian pengetahuan (cognitives), sikap (attitudes), dan motivasi (motivations), serta perilaku (behaviors) dan keterampilan (skills).

Sesuai makna tersebut, karakter identik dengan kepribadian atau akhlak. Kepribadian merupakan ciri, karakteristik, atau sifat khas diri seseorang yang bersumber dari bentukan-bentukan yang diterima dari lingkungan, misalnya keluarga pada masa kecil dan bawaan sejak lahir. Seiring dengan pengertian ini, ada sekelompok orang yang berpendapat bahwa, baik buruknya karakter manusia sudah menjadi bawaan dari lahir. Jika bawaannya baik, manusia itu akan berkarakter baik, dan sebaliknya jika bawaannya jelek, manusia itu akan berkarakter jelek.

Jika pendapat ini benar, pendidikan karakter tidak ada gunanya, karena tidak akan mungkin merubah karakter orang yang sudah ' 'taken for granted". Sementara itu, sekelompok orang yang lain berpendapat berbeda, bahwa karakter bisa dibentuk dan di upayakan sehingga pendidikan karakter menjadi lebih bermakna untuk membawa manusia memiliki karakter yang baik. Dari pengertian di atas dapat dipahami pula bahwa karakter identik dengan akhlak, sehingga karakter merupakan nilai-nilai perilaku manusia yang universal, meliputi seluruh aktivitas manusia, baik dalam rangka berhubungan dengan Tuhan, dengan diri sendiri, sesama manusia, maupun dengan lingkungan. Yang terwujud dalam pikiran, sikap, perasaan, perkataan, dan perbuatan berdasarkan norma-norma agama, hukum, tata karma, budaya, dan adat istiadat. Dari konsep karakter ini muncul konsep pendidikan karakter (character education).

Berangkat dari pemikiran bahwa segala proses belajar yang sekiranya dapat memperluas cakrawala pemikiran sebaiknya disebarluaskan. Literasi seni budaya dalam hal ini, diharapkan memiliki peran dan manfaat sebagai salah satu medium penunjang bagi pengembangan pendidikan karakter berbasis seni dan budaya di masa yang akan datang. Ketertarikan seseorang pada bidang seni dan budaya tidak hanya menjadi wacana atau minat sekolompok orang yang berlatar belakang seni saja. Dalam dunia literasi, medium seni entah itu seni rupa, drama, puisi, pantomime, musik dan tari adalah salah satu ruang bermain dan belajar dengan memberikan kesempatan seluasluasnya kepada anak untuk mengeksplorasi potensi sebagai sebuah pengalaman belajar yang asyik dan menyenangkan di sekolah.

Khusus untuk drama dan pantomim, kedua medium seni tersebut pada dasarnya bersifat improvisasi dengan tujuan pencarian pengetahuan yang meliputi setiap aspek dalam kepribadian anak, baik itu, - spiritual, moral, emosional, intelektual, dan fisik. Dalam membuat drama, anak memasuki sebuah konteks imajinasi (dunia drama), melalui penampilan fiksi tentang karakter pada lingkup tertentu.

Bagi sebagian besar masyarakat lainnya, kesenian secara umum masih sebatas media hiburan saja. Padahal seni, entah itu seni rupa, sastra, musik, tari, drama, dan seni pantomim tanpa di sadari telah menjadi bagian dari kehidupan kita sehari-hari. Jika kita cermati seni apapun bentuknya lewat karya-karyanya, seniman sebenarnya ingin menyampaikan perasaan, pemikiran dan analisisnya tentang realitas kehidupan entah itu kritik sosial, kebahagiaan, maupun duka. Mengutip apa yang dikatakan TS Eliot seorang penyair terkenal, mengatakan bahwa masa lalu dan juga masa depan adalah masa kini. Pernyataan ini menegaskan bahwa masa lalu tidak mungkin di abaikan dalam memahami kekinian sekaligus masa depan. Masa lalu bukanlah artefak yang membatu tanpa makna, apalagi masa lalu tersebut 
merupakan jejak peradaban di setiap jamannya.

Untuk membentuk karakter, unsur yang sangat dekat dan mudah dicerna adalah dengan olah seni budaya. Olah seni budaya menjadi komponen penting dalam membangun karakter. Karena disamping untuk menanamkan kecintaan pada seni budaya yang dimilikinya, juga kecintaan seni akan memupuk pribadi yang berperasaan lembut, kepekaan, rasa empati yang tinggi terhadap sesama dan lingkungannya. Kamaril Wardani dalam Kusumastuti, pendidikan dapat mengolah kecerdasan emosi seorang anak, karena di dalam pendidikan seni, mengolah semua bentuk kegiatan tentang aktivitas fisik dan cita rasa keindahan yang tertuang dalam kegiatan berekspresi, bereksplorasi, berkreasi dan berapresiasi melalui bahasa, rupa, bunyi, gerak dan peran.

Bapak pendiri bangsa menegaskan bahwa pembangunan karakter sangat penting dan fundamental. Membangun karakter penting karena karakter menentukan keberhasilan dan lancarnya pembangunan di segala bidang. Pembangunan karakter pada intinya bertujuan membentuk bangsa yang tangguh, kompetitif, berakhlak mulia, bertoleran, bergotong royong, berjiwa patriot, yang semuanya dijiwai oleh iman dan taqwa kepada Tuhan Yang Maha Esa. Membangun karakter menjadi tanggung jawab bersama dari lingkup keluarga, sekolah, masyarakat maupun di berbagai elemen seperti media massa, organisasi dan lembaga-lembaga.Secara verbal diakui bahwa pembangunan karakter bangsa merupakan sebuah keniscayaan dalam pembangunan dan kehidupan berbangsa dan bernegara.

Tilar (dalam Wasisto, dkk. 2005) berpendapat pendidikan karakter suatu bangsa tidak dapat dipisahkan dengan karakter dasar yang digunakan sebagai pijakan. Karakter dasar ini merupakan pemandu (guiding) kemana arah karakter akan dibawa. Penggunaan karakter dasar ini sangat dipengaruhi oleh latar belakang budaya bangsa yang bersangkuta. Karakter dasar manusia Indonesia (menurut Indonesia HeritageFound) cinta kepada
Tuhan, tanggung jawabm disiplin dan mandiri, jujur, hormat dan santun, kasih sayang, peduli, kerjasama, percaya diri, kreatif, kerja keras, pantang menyerah, keadilan dan kepemimpinan, baik dan rendah hari, toleran,cinta damai dan persatuan (dalam Musfiroh, 2008).

Sekolah sebagai lembaga pendidikan formal menjadi panutan dalam berbagai hal termasuk pendidikan karakter. Pendidikan karakter di sekolah disesuaikan dengan tingkat usia perkembangan mental peserta didik. (Mulyatiningsih).

Pendidikan karakter merupakan salah satu tujuan pendidikan nasional. Pasal I UU Sisdiknas tahun 2003 yang menyatakan bahwa satu diantara tujuan pendidikan nasional adalah mengembangkan potensi peserta didik untuk memiliki kecerdasan, kepribadian dan ahlak mulia. Dimaksudkan bahwa pendidikan tidak hanya membuat manusia cerdas tapi juga berkepribadian dan berkarakter.

Pendidikan merupakan sebuah proses yang membantu menumbuhkan, mengembangkan, mendewasakan, membuat yang tidak tertata menjadi semakin tertata, semacam proses penciptaan sebuah kultur dan tata keteraturan dalam diri maupun dalam diri orang lain. Pendidikan pada hakekatnya adalah proses penyempurnaan diri manusia terus menerus yang berlangsung dari generasi yang satu ke generasi yang lain (Koesoema A, 2011).

Pendidikan mempunyai peranan yang sangat penting dalam menyiapkan sumber daya yang berkarakter dan berkualitas. Pendidikan karakter dapat dimaknai sebagai pendidikan nilai, pendidikan budi pekerti, pendidikan moral, pendidikan watak yang bertujuan mengembangkan kemampuan siswa untuk memberikan dengan sepenuh hati keputusan baik-buruk, memelihara apa yang baik, dan mewujudkan kebaikan itu dalam kehidupan sehari-hari (RAN Kemendiknas 2010-2014). Pendidikan nilai adalah pendidikan seumur hidup dan pendidikan nilai merupakan pembentukan karakter anak didik (Borong, 2007).

Ada tiga unsur dalam pendidikan karakter yang bisa dikembangkan yaitu:

1) Pembentukan pendidikan karakter yang menumbuhkan kesadaran sebagai 
mahluk dan hamba Tuhan Yang Maha Esa.

2) Pendidikan karakter yang terkait dengan keilmuan.

3) Pendidikan karakter yang menumbuhkan rasa cinta dan bangga menjadi orang Indonesia (Kemendikbud,2011)

Menurut Merryl Goldberg (1999) pendidikan seni amat penting dalam pendidikan karena memiliki kekuatan dalam pendidikan untuk seni, pendidikan dengan seni dan pendidikan melalui seni. Pendidikan dengan dan melalui seni untuk berbagai bidang ilmu telah terbukti meningkatkan proses pembelajaran yang menyenangkan sehingga hasil yang diperoleh menjadi lebih optimal. Peran pendidikan seni sebagai media atau wahana di segala jenjang dan jenis bidang ilmu dapat berperan tidak hanya membentuk manusia memiliki sensivitas, kreativitas estetis, intuitif dan kritis terhadap lingkungannya tetap juga dapat mengembangkan potensi dasar mereka dalam belajar untuk mencapai hasil yang optimal (dalam Wardani, C.K., 2011). Ki Hajar Dewantoro telah menekankan perlunya pendidikan seni karena kehalusan budi anak didik dapat dilatih dan dikembangkan. Dalam proses pembelajaran seni, anak dilatih untuk mengaktifkan kerja otak kanan dan kiri secara seimbang. Pendidikan seni memberikan ruang kepada anak untuk belajar dan dengan cara menyenangkan.

\section{METODE PENELITIAN}

Penelitian yang dilakukan adalah penelitian kualitatif yaitu adalah suatu pendekatan penelitian yang mengungkapkan situasi sosial tertentu dengan mendeskripsikan kenyataan secara benar, dibentuk oleh kata-kata berdasarkan teknik pengumpulan dan analisis data yang relevan yang diperoleh dari situasi yang alamiah.

Untuk menjawab permasalahan dan menguji hipotesis penelitian digunakan analisis kualitatif dengan memaparkan hasil penelitian secara deskriptif. Adapun tahapan-tahapan analisis data tersebut yakni: penyusunan satuan atau koding data, kategorisasi atau pengelompokan data, interpretasi/penafsiran makna data dan penarikan kesimpulan dan saran-saran hasil penelitian.

\section{HASIL DAN PEMBAHASAN}

Pendidikan karakter adalah suatu usaha manusia secara sadar dan terencana untuk mendidik dan memberdayakan potensi peserta didik guna membangun karakter pribadinya sehingga dapat menjadi individu yang bermanfaat bagi diri sendiri dan lingkungannya. Pendidikan karakter (character education) sangat erat hubungannya dengan pendidikan moral dimana tujuannya adalah untuk membentuk dan melatih kemampuan individu secara terus menerus guna penyempurnaan diri ke arah hidup yang lebih baik.

Secara umum fungsi pendidikan ini adalah untuk membentuk karakter seseorang peserta didik sehingga menjadi pribadi yang bermoral, berakhlak mulia, bertoleran, tangguh dan berperilaku baik. Adapun beberapa fungsi pendidikan karakter antara lain: Untuk mengembangkan potensi dasar dalam diri manusia sehingga menjadi individu yang berpikiran baik, berhati baik dan berperilaku baik, untuk membangun dan memperkuat perilaku masyarakat yang multikultur serta untuk membangun dan meningkatkan peradaban bangsa yang kompetitif dalam hubungan internasional.

Pendidikan seni budaya pada hakekatnya bersifat multidimensional yang dapat mengembangkan kemampuan dasar manusia meliputi : perseptual, intelektual, emosional, sosial, intuitif, inovatif, kreativitas, etik dan estetik. Aktualisasi seni budaya merupakan ekspresi manusia yang khas sebagai cerminan kebiasaan dan perilaku yang disepakati dalam sebuah komunitas. Keberadaan seni budaya akan terus mengalami perubahan dan kesinambungan (change dan continuity) seiring dengan kemajuan kehidupan dan kemutakhiran tekhnologi informasi yang semakin mengalir deras dalam semua sendi kehidupan. Kesadaran dan kontrol sosial terutama dari masing-masing masyarakat "pemilik" seni budaya diharapkan 
memiliki pengkhayatan yang kuat mengenai keberadaan, aktualisasi dan tata nilai yang secara intrinsik bersemayam dalam seni budaya bersangkutan. Kesadaran tersebut dapat menghasilkan sikap saling menghormati dan saling menjaga keragaman dan perbedaan budaya bangsa sendiri maupun dengan budaya bangsa lain .

\section{1) Pengembangan Pendidikan Karakter Melalui Pengembangan Budaya Sekolah}

Budaya sekolah adalah sistem nilai, kepercayaan dan norma yang diterima bersama dan dilaksanakan dengan penuh kesadaran sebbagai perilaku alami dan dibentuk oleh lingkungan dengan menciptakan pemahaman yang sama pada seluruh civitas sekolah (Ditjen PMPTK, 2007). Dari hasil penelitian Jareonsttasin (2000), budaya sekolah berpengaruh terhadap upaya pengembangan karakter siswa. Budaya sekolah yang terwujud dalam lingkungan internal sekolah memuat juga aspek lingkungan fisik, suasana psikologis dan lingkungan sosio-kultural sekolah.

Ada enam aspek yang harus diperhatikan dalam pengembangan budaya di sekolah. Keenam aspek tersebut masingmasing budaya moral spritual, budaya bersih rapi, budaya cinta tanah air, budaya setia kawan, budaya belajar dan budaya mutu. Dari keenam aspek budaya tersebut dapat dilihat bahwa aspek yang diutamakan adalah aspek-aspek yang memuat prinsip karakter, sedangkan aspek belajar dan mutu justru ada di belakang. Ini menunjukkan betapa memang seharusnya pendidikan tidak hanya mengedepankan aspek akademik dan mutu saja namun juga harus mengutamakan aspek karakternya. Hasil penelitian Jareonsttasin (2000) bahwa siswa yang memiliki karakter yang baik cenderung memiliki prestasi akademik yang tinggi.

Di lingkungan Madrasah Aliyah Negeri (MAN) 1 Palu, keenam aspek budaya di sekolah juga telah diterapkan sejak lama. Para siswa sejak awal masuk sekolah hingga tamat ditanamkan budaya moral spritual, bersih dan rapi, cintai tanah air, setia kawan, selalu belajar dan meningkatkan mutu atau kualitas. Pengembangan budaya sekolah sebagai upaya mewujudkan lingkungan sekolah yang kondusif untuk mengembangkan karakter positif siswa perlu dilakukan dengan memperhatikan beberapa prinsip. Prinsip pertama adalah berkelanjutan, yaitu bagaimana proses perencanaan, sosialisasi, pelaksanaan dan evaluasi terus dikembangkan kualitasnya. Kedua adalah pengembangan yaiyu pengorganisasian budaya sekolah agar terintegrasi dengan seluruh aktivitas sekolah, semua aspek sekolah dirancang dan diarahkan agar kondusif untuk pengembangan karakter siswa. Prinsip ketiga yaitu konsistensi, penekanan terhadap komitmen seluruh civitas sekolah dalam menerapkan pengembangan nilai-nilai karakter yang positif. Selanjutnya prinsip implementatif. Pengembangan karakter siswa tidak cukup hanya dengan pemajangan slogan, pengarahan, ceramah dan nasehat guru namun harus diwujudkan dalam ucapan, sikap dan perilaku seluruh warga sekolah. Adapun prinsip menyenangkan adalah pengembangan karakter siswa akan lebih muda jika perasaan-perasaan negatif seperti tertekan, ketakutan dan terpaksa tidak muncul dalam diri setiap siswa.

Tidak hanya aspek budaya yang diuraikan tadi, beberapa program-program yang dilakukan oleh sekolah untuk menunjang pengembangan budaya sekolah sebagai sarana pembentukan karakter siswa. Seperti gerakan santun berbahasa dan program kotak kritik dan saran yang membuat suasana sekolah dan warganya saling memperdulikan dan komunikasi, selain melatih siswa mengemukakan pendapat dan merespon lingkungan sekitarnya. Termasuk pula program kantin kejujuran yang menjadi pilihan banyak sekolah untuk melatih siswa menjadi jujur dan mandiri.

\section{2) Strategi Ideal Pembelajaran Seni Budaya Yang Berkarakter}

Dalam semua jenjang pendidikan, materi mata pelajaran seni budaya secara kurikuler terdiri dari empat sub bidang seni yang seharusnya diajarkan yakni seni rupa, seni musik, seni tari dan seni teater. Namun pada kenyataannya, pembelajaran seni 
budaya hanya diajarkan sebagai atau jika diajarkan semuanya tidak dalam bentuk yang ideal karena keterbatasan tenaga pengajar yang profesional dan kompeten di bidangnya serta waktu yang terbatas. Karena itu, diperlukan strategi yang tepat untuk mengoptimalkan pembelajaran seni budaya melalui pilihan alternatif dengan hanya memperkuat salah satu sub bidang seni berdasarkan pilihan masing-masing siswa.

Demikian halnya di lingkungan Madrasah Aliyah Negeri (MAN) 1 Palu, berbagai kegiatan seni dan budaya dalam bentuk ekstra kokurikuler yang ditawarkan untuk menjadi pilihan siswa dalam mengembangkan bakat dan kreatifitasnya. Tidak hanya dalam seni musik, seni suara dan seni tari tapi juga seni teater. Hanya saja, tidak semua sub bidang seni tersebut ditunjang oleh sumber daya manusia dan sarana prasarana yang memadai. Dalam sub bidang seni tertentu seperti drama dan seni rupa masih terkendala tenaga pendidik maupun peralatan dan tempat latihan/belajar.

Penguatan salah satu sub bidang seni dimaksudkan untuk mengoptimalkan pelaksanaan mata pelajaran seni budaya. Pertimbangannya dalam memilih sub bidang yang akan dilaksanakan (kelas/sekolah) untuk difokuskan diantaranya : ketersediaan tenaga pengajar, minat siswa, fasilitas dan sarana prasarana. Memang tidak mudah mensinkronkan hal tersebut karena itu dibutuhkan kerjasama antar guru dan sekolah baik secara formal maupun non formal untuk secara bersamasama membangun kesadaran akan pentingnya pendidikan karakter melalui penguatan seni budaya (menjaga kearifan lokal).

Ketersediaan tenaga pengajar dan peralatan sangat menunjang tingkat keberhasilan siswa dalam sub bidang seni tersebut. Seni teater dan musik tradisional misalnya yang ditunjang tenaga pendidik yang berpengalaman dan peralatan yang memadai membuat MAN 1 Palu kerap meraih prestasi dalam berbagai perlombaan baik di tingkat Kota Palu maupun Sulawesi Tengah. MAN 1 Palu merupakan salah satu sekolah yang paling aktif dalam kegiatan pementasan seni budaya melalui sanggar seni BSSA (Bengkel Seni Suara Alam) yang cukup dikenal di Lembah Palu.

Secara formal, dalam konsep yang lebih luas, pemerintah daerah melalui Satuan Kerja Perangkat Daerah (SKPD) terkait dapat saja menyusun potensi kemudian memetakan seni budaya yang dapat dikembangkan pada kawasan sekolah tertentu sebagai pusat pendidikan pengembangan seni budaya. Dengan demikian, keberadaan guru pada sekolah tertentu yang bervariasi bidang ilmu seninya dapat dioptimalkan peran profesi dan kompetensinya. Hasil pembelajaran yang spesifik ini dapat direkomendasikan untuk pertunjukan secara berkala pada kesempatan tertentu.(pameran/pertunjukan tari/teater/konser). Kemasan seperti ini tentunya tetap harus mengacu pada konsep sistem pembelajaran persekolahan dan di sisi lain dapat menguntungkan guru yang bersertifikat untuk memenuhi jumlah jam pelajaran yang dipersyaratkan tanpa harus menambahkan aktivitas lainnya yang dapat disetarakan.

Spesifikasi salah satu bidang seni dalam proses pendidikan akan mempercepat upaya membangun pendidikan karakter. Karena itu persiapan materi hingga tahap evaluasi seharusnya melalui pertimbangan yang matang. Pertimbangan tersebut meliputi pilihan jenis seni, kebermaknaan bagi kepribadian, penguatan mentalitas, memotivasi potensi inovasi dan kreativitas bagian dari kebudayaan berterima kasih dengan masyarakat setempat. Pembentukan pendidikan berkarakter yang diperoleh selama menempuh proses pembelajaran pada jenjang tertentu selayaknya didukung oleh pendidikan non formal maupun informal dimana individu tersebut bersosialisasi dalam masyarakat. Ini agar tercipta suatu kondisi dimana orang atau masyarakat di sekitarnya pun berkontribusi yang saling menjaga, mempengaruhi dan mempertahankan jati diri yang telah menjadi kebudayaan. Misalnya penguatan kebudayaan lokal melalui lagu daerah setempat, menggali dan mendesain motif lokal untuk diterapkan pada benda-benda, merekonstruksi gerakan tari untuk 
keperluan upacara masyarakat. Membentuk teater rakyat sebagai media penyadaran untuk menjadi warga negara yang baik.

Olah seni budaya menjadi komponen penting dalam membangun karakter, karena di samping untuk menanamkan kecintaan pada seni budaya yang dimilikinya, juga kecintaan pada seni akan memupuk pribadi yang berperasaan lembut, kepekaan, rasa empati yang tinggi terhadap sesama dan lingkungannya. Kamaril Wardani dalam Kusumastuti menyatakan pendidikan seni dapat mengolah kecerdasan emosi seorang anak, karena di dalam pendidikan seni mengolah semua bentuk kegiatan tentang aktivitas fisik dan cita rasa keindahan, yang tertuang dalam kegiatan berekspresi, bereksplorasi, berkreasi dan berapresiasi melalui bahasa, rupa, bunyi, gerak dan peran membentuk karakter,unsur yang sangat dekat dan mudah dicerna adalah dengan olah seni budaya. Olah seni budaya menjadi komponen penting dalam membangun karakter, karena di samping untuk menanamkan kecintaan pada seni budaya yang dimilikinya, juga kecintaan pada seni akan memupuk pribadi yang berperasaan lembut, kepekaan, rasa empati yang tinggi terhadap sesama dan lingkungannya. Kamaril Wardani dalam Kusumastuti, pendidikan seni dapat mengolah kecerdasan emosi seorang anak, karena di dalam pendidikan seni mengolah semua bentuk kegiatan tentang aktivitas fisik dan cita rasa keindahan, yang tertuang dalam kegiatan berekspresi, bereksplorasi, berkreasi dan berapresiasi melalui bahasa, rupa, bunyi, gerak dan peran

\section{KESIMPULAN}

1. Penelitian pendidikan karakter di Madrasah Aliyah Negeri 1 Palu memberikan gambaran kalau sekolah tersebut telah menerapkan pendidikan karakter berbasis seni budaya melalui metode pembiasaan. Metode tersebut diterapkan sebelum pelajaran dimulai sebagai langkah untuk pendidikan karakter kepada siswa, antara lain menanamkan disiplin tiba di sekolah tepat waktu, memberi salam kepada guru serta sholat sunnat sebelum masuk kelas. Selain itu, ada penanaman budi pekerti, bersikap santun terhadap guru, orang tua, kepatuhan terhadap aturan, penanaman nilai-nilai kebangsaan. Nilai-nilai tersebut dilakukan dengan berbagai cara, lewat menyanyikan dan mendengarkan serta penjelasan dari guru mengenai lagu-lagu tersebut dan berdoa bersama pada waktu memulai aktivitas belajar dan pada saat pulang. Nilai terakhir ini menjadi penting untuk menanamkan nilai-nilai ketakwaan, bersyukur dan sebagainya. Metode pembiasaan tersebut ditanamkan sejak kelas 1 sampai kelas 3.

2. Pendidikan karakter juga dilekatkan pada mata pelajaran secara integratif jadi tidak hanya fokus pada mata pelajaran tertentu.

3. Pembiasaan maupun pembudayaan karakter juga ditekankan pada hal-hal yang bersumber pada ajaran dan nilainilai agama maupun kebudayaan di sekolah yang diterapkan sejak dulu. Melalui metode pembiasaan ini akan terbentuk perilaku hasil dari penanaman nilai yang terpupuk secara terus menerus, berproses dan akhirnya menjadi kebiasaan

\section{REKOMENDASI}

Berdasarkan kesimpulan tersebut di atas, terdapat beberapa saran yang perlu ditindaklanjuti, yakni:

1. Perlu ada acuan tentang bahan ajar seni budaya yang dimaksud dan materi yang dipilih untuk pendidikan karakter.

2. Perlu adanya bimbingan teknis atau diklat untuk pelaksanaan pendidikan karakter khsusunya kepada para tenaga pendidik.

3. Tersedianya tenaga pendidik yang berkompeten dalam pelaksanaan pendidikan karakter guna mewujudkan tujuan dari pendidikan karakter.

4. Peran Dinas Pendidikan dan Kebudayaan atau Kementerian Agama perlu lebih ditingkatkan dalam pembentukan karakter di tingkat MAN dan sederajat. 


\section{DAFTAR RUJUKAN}

Anna Marie, dkk. (2012). Pembentukan Karakter Berbasis Pendidikan Seni dan Budaya Tingkat Sekolah Dasar di Kota Malang, Jawa Timur. Laboratorium Antropologi Untuk Riset dan Aksi (LAURA) Balai Pelestarian Nilai Budaya (BPNB) Yogyakarta. (Online), (https://www.researchgate.net/public ation/278022355) diakses 17 Januari 2019.

Borrong, R.P. (2007). Pentingnya Pendidikan Dalam Membangun Kehidupan Bangsa. KRITIS, Jurnal Studi Pembangunan Interdisipliner, XIX (2).

Istiningtyas, R. (2014). Penanaman Pendidikan Karakter Dalam Pembelajaran Seni Budaya di SMP Negeri 1 Tasikmadu Kabupaten Karanganyar. Tesis tidak diterbitkan. Magister Manajemen Pendidikan Universitas Muhammadiyah Surakarta. (Online), (http://eprints.ums.ac.id/32453/12/Na skah\%20Publikasi.pdf), diakses 10 Januari 2019

Judiani, Sri, (2010). Implementasi Pendidikan Karakter di Sekolah Dasar Mellaui Penguatan Pelaksanaan Kurikulum. Jurnal Pendidikan dan Kebudayaan, Vol 16.

Kemendikbud. (2011). Panduan Pengembangan Pendidikan Karakter Melalui Pembelajaran Aktif, Kreatif, efektif dan Menyenangkan (Pakem) di Sekolah Dasar. Jakarta: Direktorat Pembinaan Sekolah Dasar.

Koesoema A, Doni. (2011). Pendidikan Karakter : Strategi Mendidik Anak di Zaman Global. Jakarta: PT Gramedia.
(2011). Pendidik

Karakter di Zaman Keblenger. Jakarta: PT. Gramedia.

Kusumastuti, Eny Tt. (2009). Perubahan Perilaku Kecerdasan Emosional Anak Usia Dini Melalui Pendidikan Seni Tari. Semarang : Fakultas Bahasa dan Seni, Universitas Negeri Semarang.

Marzuki, dkk Tt. (2010). Pembinaan Karakter Siswa Berbasis Pendidikan Agama di Sekolah Dasar dan Sekolah Menengah Pertama di Daerah Istimewa Yogyakarta. Yogyakarta: Universitas Negeri Yogyakarta.

Mulyatiningsih, Endang. (2011). Analisis Model-Model Pendidikan Karakter Untuk Usia Anak-Anak, remaja dan Dewasa. Yogyakarta: Universitas Negeri Yogyakarta.

Musfiroh, Tadkiroatun. (2008). Pengembangan Karakter Anak Melalui Pendidikan Karakter, dalam Character Building : Bagaimana Mendidik Anak Berkarakter?. Yogyakarta : Tiara Wacana.

Muslich, Masnur. (2011) Pendidikan Karakter: Menjawab Tantangan Krisis Multidimensional. Jakarta : Bumi Aksara.

Ramli, T. (2003). Pendidikan Karakter, Angkasa, Bandung.

Rukyanto, Agus. (2009). Pendidikan Karakter Membina Persahabatan. Yogyakarta: Kanisius.

Wasisto, Broto. (2005). Pedoman Kampanye Hidup Rukun dalam Kemajemukan, dalam Character Building : Bagaimana Mendidik Anak Berkarakter. Yogyakarta: Tiara Wacana 